\title{
MORPHOLOGICAL, PHYSIOLOGICAL AND BIOCHEMICAL GENETIC IDENTIFICATION OF THREE FEMALE EGYPTIAN CAROB (Ceratonia siliqua L.) STRAINS
}

(Received: 31.12.2018)

\author{
By \\ M. A. Omran, A. Z. Hassan and Hala N. Mohamed \\ Department of olive and semi-arid zone fruits, Horticultural Research Institute, \\ Agriculture Research Center, Giza, Egypt
}

\begin{abstract}
The present study was carried out on three top wedge grafted eight year old female carob strains during 2016 and 2017 seasons. Vegetative growth, blooming, yield, fruit and seed characteristics as well as pod chemical contents were estimated. The results showed that strain 3 significantly scored the highest leaf length, leaflet length and leaflet width while strain 2 showed higher leaflet L/W ratio. Regarding blooming characteristics, strain 3 significantly surpassed the other strains in the number of flowers/inflorescence, inflorescence length and the number of flowers $/ \mathrm{cm}$. In both seasons, strain 1 was significantly the highest regarding average No. of seeds/pod, average weight of seeds/pod, seeds/pod percentage, total sugars, total phenols and fiber percentages, while strain 2 had greater protein content. Nevertheless strain 3 was significantly superior concerning yield, pod length, pod width, pod weight, pulp weight and vitamin C content. ISSR markers were able to distinguish the genetic diversity among the carob strains. The highest similarity index was recorded between strain 1 and strain 2 and also between strain 2 and strain 3, while strain 3 proved to be genetically far from strain 1.
\end{abstract}

Key words: Carob, Ceratonia siliqua L., vegetative, flowering, fruiting and seed characteristics, total sugars, total phenols, fiber percentage, protein content, vitamin C content, ISSR -PCR technique.

\section{INTRODUCTION}

Carob tree (Ceratonia siliqua L.) is a longlived evergreen tree, which belongs to the Leguminosae family and has been described as a plant with a large adaptability in the Mediterranean area (Batlle and Tous, 1997). Carob tree is drought resistant, requires little maintenance and produce a range of products from seed and pod (Fletcher, 1997). It can also be used to regenerate vegetation in areas with a mild climate and erosion problems (Tous et al., 2009). One of the major attributes to the economic value of the carob is the fact that carob can be considered as a high value cash crop, mainly due to the high industrial demands for its seeds from where gum is extracted (Biner et al., 2007). Carob bean gum (CBG) or locust bean gum (LBG) comes from the endosperm of the seed and chemically is a polysaccharide, a galactomannan. CBG is a versatile material used for many applications where they are excellent stiffeners (additive E 410) and stabilizers of emulsions, and the absence of toxicity allows their use in the textile, pharmaceutical, biomedical, cosmetics, nutrition sciences, and food industries (Karababaa and Coskunerb, 2013). Moreover, seeds powder can be used in baby foods to prevent vomiting (FAO, 2001). Carob germ flour is used as dietetic human food and it is used as a potential ingredient in cereal derived foods for celiac people (Fillet and Roulland, 1998). The protein content of carob germ flour seeds is higher than those of other beans (Maza et al., 1989).

Carob pods have a good nutritional value, a long shelf-life (2-3 years) and are relatively cheap (Bulca, 2016). Carob kibble (seedless pods) have been found to be beneficial in the control of many health problems such as diabetes, heart diseases, over weight and colon cancer due to their antidiabetic, antioxidant, anticarcinogenic and anti-inflammatory activities as well as cholesterol-lowering effect and metabolic properties. Also, carob flour has been of considerable value as a dietetic therapy for infantile diarrheal disturbance and bacterial 
dysentery in terms of shortening the duration of the disease (Nasar-Abbas et al., 2016). Carob kibble also contains very low fat (about $1 \%$ ) and sodium contents making it a healthy food ingredient (Makris and Kefalas, 2004). Battle and Tous (1997) reported that seven amino acids were found in carob pods. Also, it was used for production of bread. Carob powder is a natural sweetener with flour and appearance similar to chocolate; therefore it is often used as cocoa substitute with an advantage that carob is caffeine, theo bromine and oxalic acid free (Iipumbu, 2008). Carob powder is a good source of vitamins E, D, C, Niacin, B6 and folic acid (Youssef et al., 2013).

Many previous studies were published dealing with carob vegetative growth, blooming, yield, fruit and seed characteristics as well as genetic identification (Batlle and Tous, 1997; Konaté et al., 2007; Iipumbu, 2008; Tous et al., 2009; Gubbuk et al., 2010; Naghmouchi et al., 2012; Haddarah et al., 2013; Awad, 2014; El Kahkahi et al., 2015 and El Batal et al., 2016).

The premium molecular analysis of carob tree using RAPD markers was reported by Konaté et al. (2007). ISSR is considered to achieve higher reproducibility than RAPD markers and is reported to detect a high portion of genomic variation than RFLP (Zietkiewicz et al., 1994).

World production is about 158,609 tons in 2016 and the main producers are Portugal $25.46 \%)$, Italy (18.24\%), Spain (16.51\%), Morocco (13.89\%) and Turkey (8.45\%) of the world production (FAO, 2016). In Egypt carob tree is found sporadically, however the Ministry of Agriculture and Land Reclamation (2016) reported that carob area is about 6 feddans in 2015 which is a very small area regarding the compatibility of carob tree with Egypt's climate conditions, water deficiency and the increase of declining cultivated lands, taking into consideration it generates profitable economic returns. In spite of the great interest in carob and its useful different applications, few studies concerning Egyptian carob are available. The aim of this study was to determine the performance of three female Egyptian strains growing at the experimental orchard of Horticultural Research Institute, Agriculture Research Center, Giza Governorate, Egypt to select the most promising strain for increasing carob orchard's area, especially focusing on seed content and pod production.

\section{MATERIALS AND METHODS}

\subsection{Plant material}

This study was carried out during 2016 and 2017 seasons on three female top wedge grafted carob strains. These strains were previously evaluated under Bourg El-Arab region of Alexandria Governorate conditions and proved to be the best (Awad, 2014). The eight year old trees were planted on loamy soil and were grown at the experimental orchard of the Horticultural Research Institute, Agriculture Research Center, Giza Governorate (Latitude 30 03, Longitude 31 13 and Elevation 18.6), Egypt. Pollen was produced by male carob tree. The trees were grown under the same environmental conditions and cultural practices.

The Average monthly temperature $\left({ }^{\circ} \mathrm{C}\right)$ and relative humidity $(\%)$ at Giza Governorate, Egypt are presented in Fig. (1 and 2) as follows:
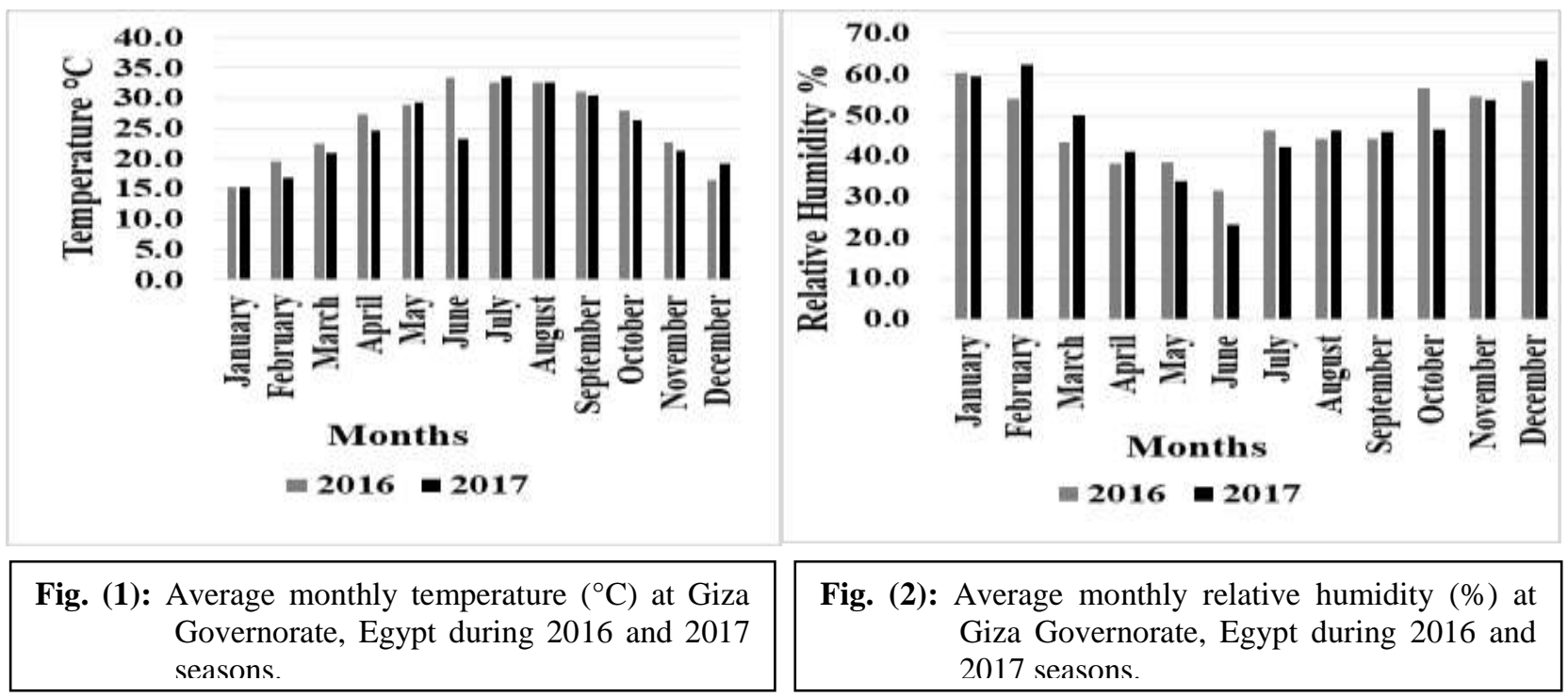

Fig. (2): Average monthly relative humidity (\%) at Giza Governorate, Egypt during 2016 and 2017 seasons. 


\subsection{Vegetative growth parameters}

A collection of 24 leaves were collected to measure average leaf length $(\mathrm{cm})$, leaflet number, leaflet length and width $(\mathrm{cm})$. Also, canopy nature, bark appearance, leaf and leaflet shapes as well as the most leaflet arrangement were recorded.

\subsection{Blooming characteristics}

The beginning of flowering, the full bloom and the end of flowering were determined. Flower color, flower and sepal shapes were recorded. Average number of flowers/ inflorescence was counted after selecting 15 inflorescences for each strain. Also, average inflorescence length $(\mathrm{cm})$ and the number of flowers/cm were estimated.

\subsection{Yield and fruit characteristics}

After harvesting, yield $(\mathrm{Kg})$ was recorded, then 12 pods were collected from each strain. Average pod length and width $(\mathrm{cm})$ were measured. Average pod shape index was recorded as the ratio of length over width. Average pod thickness $(\mathrm{cm})$ was detected with the Vernier caliper. Average pod weight (g), pod volume $\left(\mathrm{ml}^{3}\right)$ was assessed by submerging it in a known volume of water in a graduated cylinder $\left(1000 \mathrm{~cm}^{3}\right)$, average pod density $\left(\mathrm{g} / \mathrm{ml}^{3}\right)$ was calculated by the formula pod weight/pod volume and average pulp weight (g) were recorded.

\subsection{Seed characteristics}

Three replicates each one contains 10 seeds were used to determine the upcoming data average seed length, width, thickness $(\mathrm{cm})$ and weight $(\mathrm{g})$, seed shape index, average No. of seeds/pod, average weight of seeds/pod and average seed /pod percentage.

\subsection{Pulp chemical contents}

The upcoming chemical characteristics were determined in seedless pods as follows:

2.6.1. Total sugars percentage according to Miller (1959) and Kawamura (1967) methods.

2.6.2.Total phenols percentage determined according to Swain and Hillis (1959) spectrophotometrically.

2.6.3.Tannins percentage was determined according to AOAC (1970).

2.6.4. Total flavonoids content $(\mathrm{mg} / \mathbf{1 0 0 g})$ as described by Djeridane et al. (2006).

2.6.5.Total protein content $(\mathrm{g} / \mathbf{1 0 0 g})$ was calculated by determination of nitrogen content using the modified microkjeldahl method as described by Plummer (1971) then crude protein content was estimated by multiplying total nitrogen by 6.25 (AOAC, 1990).

2.6.6. Fiber percentage was measured according to AOAC (2005).

2.6.7. Vitamin $C$ content (ascorbic acid $\mathbf{m g} / \mathbf{1 0 0 g}$ ) was determined according to AOAC (1990) method.

\subsection{Experimental layout}

The experimental treatments (three female carob strains) were arranged in randomized complete block design. Data recorded in 2016, and 2017 seasons were subjected to analysis of variance (ANOVA) according to Snedecor and Cochran (1980) and the means were differentiated using Duncan multiple tests at the level of probability 5\% (Waller and Duncan, 1969).

\subsection{Molecular Marker Analysis 2.8.1. ISSR-PCR technique \\ 2.8.1.1. DNA Extraction}

DNA extraction was performed as described by Dellaporta et al. (1983). About $0.1 \mathrm{~g}$ fresh weight of plant tissues of each carob strain separately grounded to fine powder in liquid N2 in a mortar were added to $600 \mathrm{ul}$ of extraction buffer $(100 \mathrm{mM}$ Tris- $\mathrm{HCl}, \mathrm{pH}$ 8.0, $50 \mathrm{mM}$ EDTA and $0.5 \mathrm{M} \mathrm{NaCl}$ ) and $0.2 \mathrm{ml} 20 \%$ SDS were added. The mixture was incubated at $65{ }^{\circ} \mathrm{C}$ in water bath for $20 \mathrm{~min}$. then $1 \mathrm{ml}$ of phenol, chloroform and isoamyl alcohol (25:24:1) were added. Centrifugation was performed at 10.000 rpm for $10 \mathrm{~min}$. The supernatant of each sample was transferred separately to a new tube, and then $1 \mathrm{ml}$ of chloroform and isoamyl (24:1) were added. Centrifugation was performed at 10.000 $\mathrm{rpm}$ for $10 \mathrm{~min}$. The supernatant of each sample was transferred separately to a new tube, then 1 $\mathrm{ml}$ of isopropanol was added and then kept overnight in a freezer. Centrifugation was performed at $10.000 \mathrm{rpm}$ for $10 \mathrm{~min}$. The resulting pellets containing DNA were resuspended in $1 \mathrm{ml}$ ethanol. Centrifugation was performed at $10.000 \mathrm{rpm}$ for $2 \mathrm{~min}$. The DNA pellets were re-suspended in 80 ul TE buffer (10 mM Tris $-\mathrm{HCl}, \mathrm{pH} 8.0$ and $1 \mathrm{mM}$ EDTA).

DNA quality was examined by agarose electrophoresis $1.5 \%$ and DNA concentration was quantified by means of calibration. Dependence was measured by photo Capt MW V 3.0 software. For ISSR, aliquots of ng/ul were prepared and stored at $-20^{\circ} \mathrm{C}$ buffer.

\subsubsection{Inter Simple Sequence Repeat ISSR- PCR Analysis}

ISSR analysis for four ISSR primers (Table 1) were performed as described by Adawy et al. 
Table (1): List of the primer names and their nucleotide sequences used in the study for ISSR procedure.

\begin{tabular}{|c|c|}
\hline Name & Primer sequences $\left(\mathbf{5}^{\prime} \rightarrow \mathbf{3}^{\prime}\right)$ \\
\hline HB-8 & GAG AGA GAG AGA GG \\
\hline HB-9 & GTG TGT GTG TGT GC \\
\hline HB-12 & CAC CAC CAC GC \\
\hline HB-14 & CTC CTC CTC GC \\
\hline
\end{tabular}

(2004) and Hussein et al. (2006).

\subsubsection{Gel documentation}

Gels were photographed, scanned and analyzed using Gel Doc Vilber Lourmat system (Vilber Company, France) to capture the image and to calculate band intensities.

\section{RESULTS AND DISCUSSIONS}

\subsection{Vegetative growth parameters}

\subsubsection{Average leaf length}

In 2016 season (Table 2) it was obvious that strain 3 gave the highest value $(16.87 \mathrm{~cm})$ with insignificant difference with strain $1(16.47 \mathrm{~cm})$. The lowest leaf length was given by strain 2 $(16.03 \mathrm{~cm})$ with insignificant difference with strain $1(16.47 \mathrm{~cm})$. In 2017 season, strain 3 was significantly superior in this concern $(19.84 \mathrm{~cm})$ followed by strain $1(17.88 \mathrm{~cm})$, then strain 2 $(16.76 \mathrm{~cm})$ with significant difference. Similar results were obtained by El Kahkahi et al. (2015) who found that the average leaf length of seven Moroccan carob populations ranged 13.49 $18.58 \mathrm{~cm}$.

\subsubsection{Average leaflets number}

Strain 1 showed the highest significant value (8.95), while strain 2 came next (8.43) with insignificant difference with strain 3 (8.28) during 2016 season (Table 2). Strain 2 recorded the top significant value (9.29), followed by strain 1 (8.95) and finally strain 3 (8.71) with insignificant difference between them during 2017 season. Similarly, El Kahkahi et al. (2015) found that the average number of leaflets/leaf varies from $8-10$.

\subsubsection{Average leaflet length}

From Table (2) it can be noticed in both seasons of the study that strain 3 significantly exceeded the others (6.65 in 2016 season and 7.01 in 2017 season) followed by strain 2 which didn't differ significantly with strain 1 (5.86 and 5.82 respectively in 2016 season as well as 5.81 for both of them in 2017 season). The above results are in harmony with El Kahkahi et al. (2015) who reported that values corresponding to the length of the leaflets respectively varied from $4.98 \mathrm{~cm}$ to $6.55 \mathrm{~cm}$.

\subsubsection{Average leaflet width}

Strain 3 significantly surpassed the other carob strains during both seasons of the study (5.33 and $4.83 \mathrm{~cm}$, respectively, in Table 2), followed by strain 2, then strain 1 in 2016 season (4.05 and 3.85, respectively), while in 2017 season, strain 1 was the second (3.97) and strain 2 was the third (3.79) with significant differences in both seasons. The above results are in line with El Kahkahi et al. (2015) who report at that the width of the leaflets varied from $3.08 \mathrm{~cm}$ to $4.55 \mathrm{~cm}$.

\subsubsection{Average leaflet $L / W$ ratio}

In 2016 season, strain 1 came first (1.51) as shown in Table (2), with insignificant difference with strain 2 (1.45) and finally came strain 3 (1.25) with significant differences with the others. In 2017 season strain 2 significantly recorded the highest value (1.53) while strain 1 (1.46) didn't differ significantly from stain 3 (1.45).

Table (2): Average leaf length, leaflet number, leaflet length and leaflet width as well as leaflet $\mathrm{L} / \mathrm{W}$ ratio of the studied carob strains during 2016 and 2017 seasons.

\begin{tabular}{|c|c|c|c|c|c|c|c|c|c|c|}
\hline \multirow{2}{*}{$\begin{array}{c}\text { Strain } \\
\text { No. }\end{array}$} & \multicolumn{2}{|c|}{$\begin{array}{c}\text { Average leaf } \\
\text { length }(\mathbf{c m})\end{array}$} & \multicolumn{2}{|c|}{$\begin{array}{c}\text { Average leaflet } \\
\text { No. }\end{array}$} & \multicolumn{2}{c|}{$\begin{array}{c}\text { Average leaflet } \\
\text { length }(\mathbf{c m})\end{array}$} & \multicolumn{2}{c|}{$\begin{array}{c}\text { Average leaflet } \\
\text { width }(\mathbf{c m})\end{array}$} & \multicolumn{2}{|c|}{$\begin{array}{c}\text { Average leaflet } \\
\text { L/W ratio }\end{array}$} \\
\cline { 2 - 12 } & $\mathbf{2 0 1 6}$ & $\mathbf{2 0 1 7}$ & $\mathbf{2 0 1 6}$ & $\mathbf{2 0 1 7}$ & $\mathbf{2 0 1 6}$ & $\mathbf{2 0 1 7}$ & $\mathbf{2 0 1 6}$ & $\mathbf{2 0 1 7}$ & $\mathbf{2 0 1 6}$ & $\mathbf{2 0 1 7}$ \\
\hline Strain1 & $16.47 \mathrm{ab}$ & $17.88 \mathrm{~b}$ & $8.95 \mathrm{a}$ & $8.95 \mathrm{~b}$ & $5.82 \mathrm{~b}$ & $5.81 \mathrm{~b}$ & $3.85 \mathrm{c}$ & $3.97 \mathrm{~b}$ & $1.51 \mathrm{a}$ & $1.46 \mathrm{~b}$ \\
\hline Strain2 & $16.03 \mathrm{~b}$ & $16.76 \mathrm{c}$ & $8.43 \mathrm{~b}$ & $9.29 \mathrm{a}$ & $5.86 \mathrm{~b}$ & $5.81 \mathrm{~b}$ & $4.05 \mathrm{~b}$ & $3.79 \mathrm{c}$ & $1.45 \mathrm{a}$ & $1.53 \mathrm{a}$ \\
\hline Strain3 & $16.87 \mathrm{a}$ & $19.84 \mathrm{a}$ & $8.28 \mathrm{~b}$ & $8.71 \mathrm{~b}$ & $6.65 \mathrm{a}$ & $7.01 \mathrm{a}$ & $5.33 \mathrm{a}$ & $4.83 \mathrm{a}$ & $1.25 \mathrm{~b}$ & $1.45 \mathrm{~b}$ \\
\hline
\end{tabular}

Means designated with the same letter within column in each season is not significantly differ at 0.05 level of probability. 


\subsubsection{Canopy nature, bark appearance, leaf and leaflet shapes as well as the most leaflet arrangement}

As shown in Table (3), all the three strains showed spread canopy nature, smooth bark appearance, odd or even pinnate leaf shape, and oval leaflet shape (Fig. 3). Similar results were observed by El Kahkahi et al. (2015). For strain 1 and 2 the alternate leaflet arrangement was the most but it was the opposite for strain 3 .

\subsection{Blooming characteristics}

\subsubsection{Blooming dates}

All the investigated carob tree strains began flowering in September but the fruit set didn't continue because of the high temperature till the beginning of November in both seasons.

Full bloom occurred at the mid of November and the end of flowering period was at the end of December. Iipumbu (2008) reported that the flowering season was from September to November.

\subsubsection{Flower color, flower and sepal shapes}

Flower color was green, flower shape was cluster and sepal shape was free for all the studied strains. These results are in line with El Kahkahi et al. (2015).

\subsubsection{Average number of flowers/inflorescences}

Strain 3 had the highest values (Table, 4) then strain 2 followed by strain 1 with a very clear significant difference in both seasons of study. The same trend was found by El Kahkahi et al. (2015) who noted that the number of flowers per cluster ranged from 29.78 to 34.32 .

\subsubsection{Average inflorescence length $(\mathrm{cm})$}

In the $1^{\text {st }}$ season significant differences were observed between the three strains, strain 3 gave the highest value, strain 1 was the second and strain 2 was the last. In the $2^{\text {nd }}$ season strain 3 significantly topped, strain 2 came next with insignificant difference with strain 1 as shown in Table (4) and Fig. (4). El Kahkahi et al. (2015) reported similar results.

Table (3): Canopy nature, bark appearance, leaf shape, leaflet shape and the most leaflet arrangement of the studied carob strains during 2016 and 2017 seasons.

\begin{tabular}{|c|c|c|c|c|c|}
\hline Strain No. & $\begin{array}{c}\text { Canopy } \\
\text { nature }\end{array}$ & Bark appearance & Leaf shape & Leaflet shape & $\begin{array}{c}\text { The most leaflet } \\
\text { arrangement }\end{array}$ \\
\hline Strain $\mathbf{1}$ & Spread & Smooth & $\begin{array}{c}\text { Odd or even } \\
\text { pinnate }\end{array}$ & Oval & Alternate \\
\hline Strain $\mathbf{2}$ & Spread & Smooth & $\begin{array}{c}\text { Odd or even } \\
\text { pinnate }\end{array}$ & Oval & Alternate \\
\hline Strain 3 & Spread & Smooth & $\begin{array}{c}\text { Odd or even } \\
\text { pinnate }\end{array}$ & Oval & Opposite \\
\hline
\end{tabular}
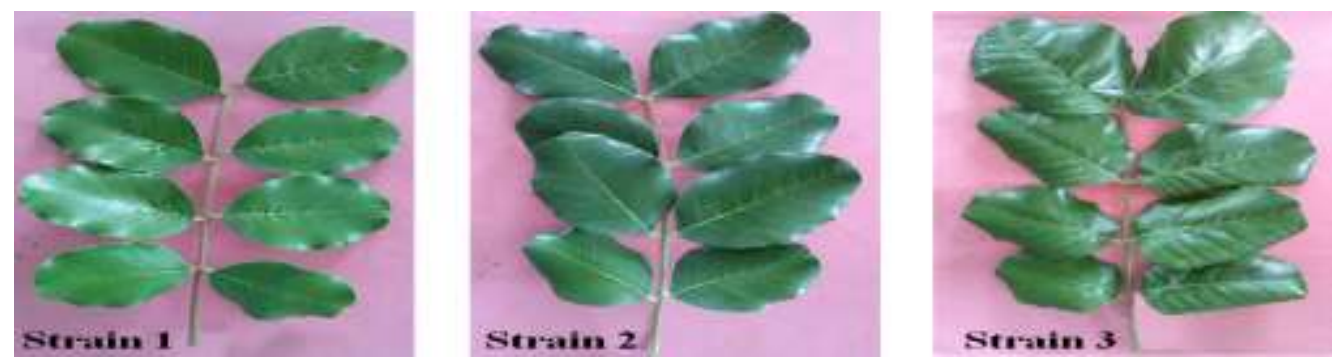

Fig. (3): Leaf of the studied carob strains.

Table (4): The blooming characteristics of the studied carob strains during 2016 and 2017 seasons.

\begin{tabular}{|c|c|c|c|c|c|c|}
\hline \multirow{2}{*}{ Strain No. } & \multicolumn{2}{|c|}{$\begin{array}{c}\text { Average No. of } \\
\text { Flowers/inflorescence }\end{array}$} & \multicolumn{2}{c|}{$\begin{array}{c}\text { Average } \\
\text { inflorescence length } \\
\text { (cm) }\end{array}$} & \multicolumn{2}{|c|}{$\begin{array}{c}\text { Average No. of Flowers/ } \\
\text { cm }\end{array}$} \\
\cline { 2 - 6 } & $\mathbf{2 0 1 6}$ & $\mathbf{2 0 1 7}$ & $\mathbf{2 0 1 6}$ & $\mathbf{2 0 1 7}$ & $\mathbf{2 0 1 6}$ & $\mathbf{2 0 1 7}$ \\
\hline Strain 1 & $37.34 \mathrm{c}$ & $36.80 \mathrm{c}$ & $7.60 \mathrm{~b}$ & $7.23 \mathrm{~b}$ & $5.05 \mathrm{c}$ & $5.10 \mathrm{~b}$ \\
\hline Strain 2 & $43.22 \mathrm{~b}$ & $38.00 \mathrm{~b}$ & $6.55 \mathrm{c}$ & $7.65 \mathrm{~b}$ & $6.61 \mathrm{~b}$ & $4.97 \mathrm{~b}$ \\
\hline Strain 3 & $69.11 \mathrm{a}$ & $60.93 \mathrm{a}$ & $9.30 \mathrm{a}$ & $8.36 \mathrm{a}$ & $7.43 \mathrm{a}$ & $7.32 \mathrm{a}$ \\
\hline
\end{tabular}

Means designated with the same letter within column in each season is not significantly differ at 0.05 level of probability. 


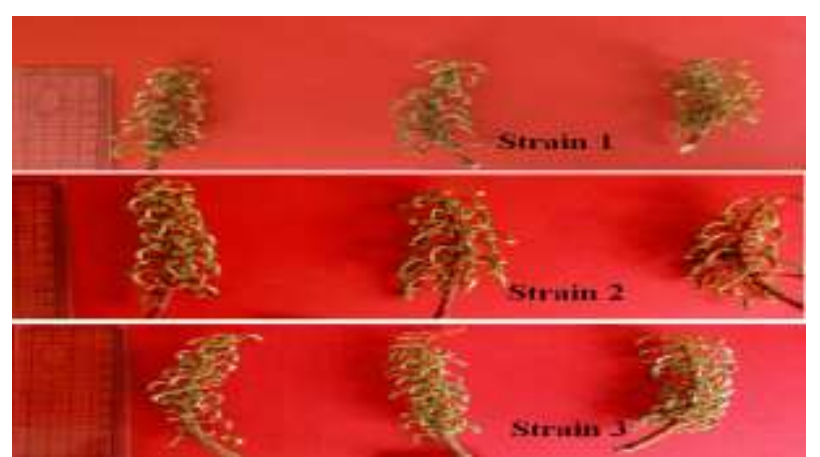

Fig. (4): The inflorescence length of the studied carob strains.

\subsubsection{Average number of flowers/cm}

The highest values were significantly recorded by strain 3 in both seasons (Table 4). Strain 2 significantly showed higher value than strain 1 in 2016 season while in 2017 season they switched their positions with insignificant difference.

\subsection{Yield and fruit characteristics 3.3.1. Yield (Kg)}

It is obvious from Table (5) that the highest significant yield value was given by strain 3 followed by strain 1 then strain 2 with significant differences between them during 2016 season (38.52, 31.4 and $10.0 \mathrm{~kg}$, respectively) and 2017 season $(39.41,33.6$ and $12 \mathrm{~kg}$, respectively). The above results perfectly agree with the findings of El Kahkahi et al. (2015) who noted that yield varied from 10.4 to $550 \mathrm{~kg} /$ tree of seven Moroccan carob populations.

\subsubsection{Average pod length and width $(\mathrm{cm})$}

In both seasons as shown in Table (5) and Fig. (5) strain 3 significantly surpassed the others with insignificant differences between strain 1 and 2. Haddarah et al. (2013) recorded similar results.

\subsubsection{Average pod Shape index}

Significant differences were observed in the $1^{\text {st }}$ season (Table 5), strain 3 was superior (9.01) then strain 1 (8.00) and finally strain 2 (7.47). In the $2^{\text {nd }}$ season, strain 2 recorded the highest significant value (7.65), followed by strain 1 (7.13), then strain 3 (6.91) with insignificant difference between them. Similar results were reported on eight carob female strains in Bourg El-Arab region of Alexandria Governorate that size index ranged from 5.45 to 14.87 (Awad, 2014).

\subsubsection{Average pod thickness $(\mathrm{cm})$}

Data in Table (5) show that in the $1^{\text {st }}$ season, strain 2 recorded the highest value $(0.97 \mathrm{~cm})$ then strain $3(0.88 \mathrm{~cm})$ and finally strain $1(.079$ $\mathrm{cm}$ ) with significant differences but in the $2^{\text {nd }}$ season, the highest value was shown by strain 1 $(0.97 \mathrm{~cm})$ with insignificant difference with strain $3(0.95 \mathrm{~cm})$ while, strain 2 came next $(0.85 \mathrm{~cm})$ with significant difference. These findings are in line with Haddarah et al. (2013) who found that pod thickness of nine carob varieties from different regions of Lebanon ranged $0.48 \pm 0.04-0.92 \pm 0.11 \mathrm{~cm}$.

\subsubsection{Average pod weight (g)}

It is clear from Table (6) that strain 3 recorded the highest significant value in both seasons of the study, followed by strain 2 , then strain 1 in 2016 season with significant difference, while in 2017 season, they switched their positions with insignificant difference between them. The same results were obtained by Haddarah et al. (2013) who noted that pod weight of nine Lebanese varieties recorded $8.93 \pm 1.67-36.85 \pm 3.97 \mathrm{~g}$.

\subsubsection{Average pod volume $\left(\mathrm{ml}^{3}\right)$}

In Table (6) pod volume of strain 1, 2 and 3 recorded 20.67, 19.00 and $17.33 \mathrm{ml}^{3}$, respectively and the only significant difference was between strain 1 and 3 in the $1^{\text {st }}$ season. However, in the $2^{\text {nd }}$ season, strain 3, 1 and 2 scored $24.00,19.33$ and $15.33 \mathrm{ml}^{3}$, respectively, with significant differences. Similar findings were reported where pod volume ranged $9.95 \pm 1.91-47.90 \pm 4.68 \mathrm{ml}^{3}$ (Haddarah et al., 2013).

\subsubsection{Average pod density $\left(\mathrm{g} / \mathrm{ml}^{3}\right)$}

Data presented in Table (6) showed that strain 3 significantly came first $\left(1.23 \mathrm{~g} / \mathrm{ml}^{3}\right)$ then strain 2 was the second $\left(0.95 \mathrm{~g} / \mathrm{ml}^{3}\right)$, while strain 1 was the last $\left(0.88 \mathrm{~g} / \mathrm{ml}^{3}\right)$, with insignificant difference with strain 2 in 2016 season but in 2017 season, strain 2 significantly gave the highest value $\left(1.00 \mathrm{~g} / \mathrm{ml}^{3}\right)$, while the two other strains showed insignificant difference between them $\left(0.80 \mathrm{~g} / \mathrm{ml}^{3}\right.$ for strain 1 and $0.78 \mathrm{~g} / \mathrm{ml}^{3}$ for strain 3). Haddarah et al. (2013) found different pod density results of nine Lebanese carob varieties.

\subsubsection{Average pulp weight (g)}

In both seasons as shown in Table (6) strain 3 was significantly superior (18.63 and $16.31 \mathrm{~g}$, respectively), while insignificant differences were observed between strain 1 and strain 2 . The above results are in harmony with El Batal et al. (2016). Carob kibble (seedless pods) have been found to be beneficial in controlling many health problems. It contains very low fat, sodium content, a good source of 7 amino acids and some vitamins. Pulp weight is an important 

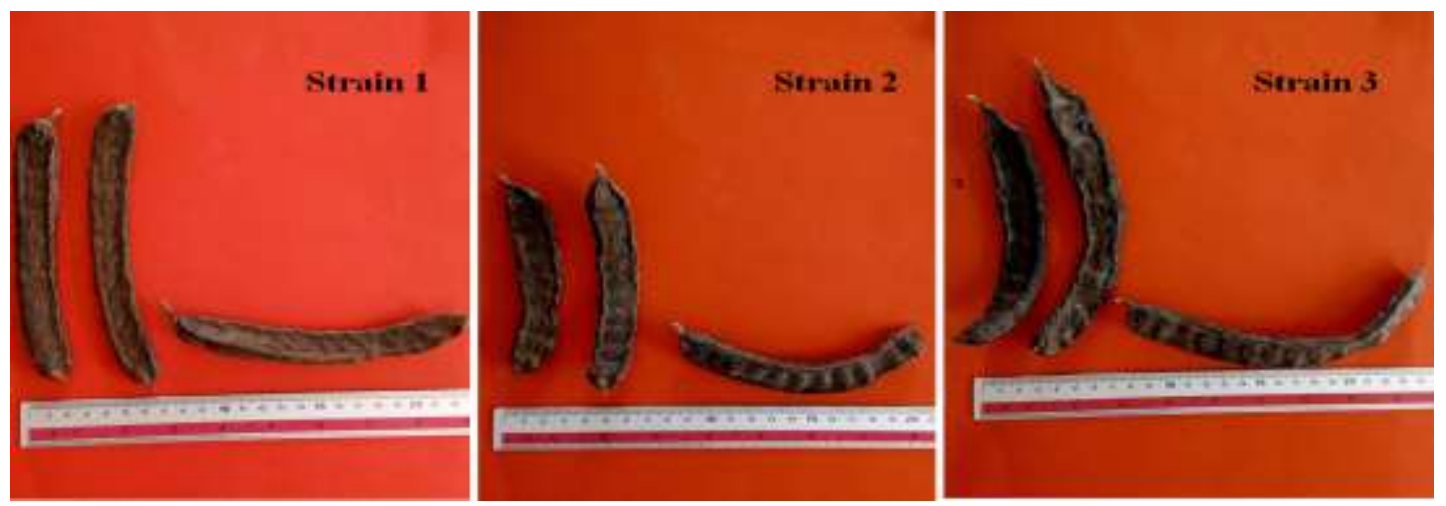

Fig. (5): Pod length and width of the studied carob strains.

Table (5): Yield, average pod length, pod width, pod shape index and pod thickness of the studied carob strains during 2016 and 2017 seasons.

\begin{tabular}{|c|c|c|c|c|c|c|c|c|c|c|}
\hline \multirow{2}{*}{$\begin{array}{c}\text { Strain } \\
\text { No. }\end{array}$} & \multicolumn{2}{|c|}{$\begin{array}{c}\text { Yield } \\
\text { (kg) }\end{array}$} & $\begin{array}{c}\text { Average pod length } \\
(\mathbf{c m})\end{array}$ & $\begin{array}{c}\text { Average pod width } \\
(\mathbf{c m})\end{array}$ & \multicolumn{2}{|c|}{$\begin{array}{c}\text { Average pod Shape } \\
\text { index }\end{array}$} & \multicolumn{2}{c|}{$\begin{array}{c}\text { Average pod } \\
\text { thickness }(\mathbf{c m})\end{array}$} \\
\cline { 2 - 13 } & 2016 & 2017 & 2016 & 2017 & 2016 & 2017 & 2016 & 2017 & 2016 & 2017 \\
\hline Strain 1 & $31.4 \mathrm{~b}$ & $33.6 \mathrm{~b}$ & $16.23 \mathrm{~b}$ & $14.62 \mathrm{~b}$ & $2.03 \mathrm{~b}$ & $2.05 \mathrm{~b}$ & $8.00 \mathrm{~b}$ & $7.13 \mathrm{~b}$ & $0.79 \mathrm{c}$ & $0.97 \mathrm{a}$ \\
\hline Strain 2 & $10.00 \mathrm{c}$ & $12.00 \mathrm{c}$ & $15.46 \mathrm{~b}$ & $15.08 \mathrm{~b}$ & $2.07 \mathrm{~b}$ & $1.97 \mathrm{~b}$ & $7.47 \mathrm{c}$ & $7.65 \mathrm{a}$ & $0.97 \mathrm{a}$ & $0.85 \mathrm{~b}$ \\
\hline Strain 3 & $38.52 \mathrm{a}$ & $39.41 \mathrm{a}$ & $20.81 \mathrm{a}$ & $17.20 \mathrm{a}$ & $2.31 \mathrm{a}$ & $2.49 \mathrm{a}$ & $9.01 \mathrm{a}$ & $6.91 \mathrm{~b}$ & $0.88 \mathrm{~b}$ & $0.95 \mathrm{a}$ \\
\hline
\end{tabular}

Means designated with the same letter within column in each season is not significantly differ at 0.05 level of probability.

Table (6): Average pod weight, pod volume, pod density and pulp weight of the studied carob strains during 2016 and 2017 seasons.

\begin{tabular}{|c|c|c|c|c|c|c|c|c|}
\hline \multirow{2}{*}{ Strain No. } & \multicolumn{2}{|c|}{\begin{tabular}{c} 
Average pod weight $(\mathbf{g})$ \\
\cline { 2 - 9 }
\end{tabular}} & \multicolumn{2}{|c|}{$\begin{array}{c}\text { Average pod volume } \\
\left(\mathbf{m l}^{\mathbf{3}}\right)\end{array}$} & \multicolumn{2}{|c|}{$\begin{array}{c}\text { Average pod density } \\
\left(\mathbf{g} / \mathbf{m l}^{\mathbf{3}}\right)\end{array}$} & \multicolumn{2}{|c|}{$\begin{array}{c}\text { Average pulp weight } \\
(\mathbf{g})\end{array}$} \\
\hline Strain 1 & $18.04 \mathrm{c}$ & $\mathbf{2 0 1 7}$ & $\mathbf{2 0 1 6}$ & $\mathbf{2 0 1 7}$ & $\mathbf{2 0 1 6}$ & $\mathbf{2 0 1 7}$ & $\mathbf{2 0 1 6}$ & $\mathbf{2 0 1 7}$ \\
\hline Strain 2 & $19.86 \mathrm{~b}$ & $14.60 \mathrm{~b}$ & $20.67 \mathrm{a}$ & $19.33 \mathrm{~b}$ & $0.88 \mathrm{~b}$ & $0.80 \mathrm{~b}$ & $15.07 \mathrm{~b}$ & $13.14 \mathrm{~b}$ \\
\hline Strain 3 & $21.22 \mathrm{a}$ & $18.62 \mathrm{a}$ & $17.33 \mathrm{~b}$ & $24.00 \mathrm{a}$ & $1.23 \mathrm{a}$ & $0.78 \mathrm{~b}$ & $18.63 \mathrm{a}$ & $16.31 \mathrm{a}$ \\
\hline
\end{tabular}

Means designated with the same letter within column in each season is not significantly differ at 0.05 level of probability.

measurement for industrial food products such as carob flour, powder, jam, juice and molasses.

\subsection{Seed characteristics}

\subsubsection{Average seed length $(\mathrm{cm})$}

As shown in Table (7), the highest value was recorded by strain $2(1.04 \mathrm{~cm})$ with insignificant difference with strain $3(1.03 \mathrm{~cm})$ and finally came strain 1 with significant differences with the others $(0.95 \mathrm{~cm})$ in the $1^{\text {st }}$ season. In the $2^{\text {nd }}$ season, strain 3 significantly surpassed $(0.98 \mathrm{~cm})$ the others with insignificant difference between strain 1 and 2 (0.88 and $0.89 \mathrm{~cm}$, respectively). Similarly, Gubbuk et al. (2010) reported that seed length of the three Turkish genotypes under study ranged $8.07-10.41 \mathrm{~mm}$.

\subsubsection{Average seed width $(\mathrm{cm})$}

In 2016 season, (Table 7) there was an insignificant difference between the three strains. In 2017 season, the only significant difference was observed between strain $3(0.72$ $\mathrm{cm})$, and strain $1(0.63 \mathrm{~cm})$. The above results are in harmony with Gubbuk et al. (2010).

\subsubsection{Average seed shape index}

In 2016 season, strain 2 (1.39) significantly topped the two other strains with insignificant difference between them. In 2017 season, strain 1 (1.40) significantly surpassed the others with insignificant difference between them as shown in Table (7).

\subsubsection{Average seed weight (g)}

Strain 1 and 2 recorded $0.20 \mathrm{~g}$ in 2016 (Table 7) while, strain 3 recorded $0.17 \mathrm{~g}$ with significant differences with the others. However, in 2017 strain 3 significantly came first with 
$0.21 \mathrm{~g}$ seed weight. Strain 1 came next with insignificant difference with strain 2 (0.18 and $0.17 \mathrm{~g}$, respectively). Similarly, Tous et al. (2009) noticed that average seed weight of four carob cultivars in northeastern Spain ranged $0.19-0.24 \mathrm{~g}$.

\subsubsection{Average seed thickness $(\mathrm{cm})$}

Data of both seasons of the study as shown in Table (7) proved that insignificant difference was observed between strains 2 and 3. Strain 1 recorded the lowest values with insignificant difference just in 2016 season with strain 2 . Gubbuk et al. (2010) found that seed thickness ranged 3.40- $4.14 \mathrm{~mm}$ of three genotypes grown in Turkey.

\subsubsection{Average number of seeds/pod}

In the first season, (Table 8) data revealed that strain 3 gained the highest value (14.89 seeds) with insignificant difference with strain 1 (14.67 seeds) while, strain 2 recorded the lowest value with significant differences with the others (10.00 seeds). In the second season, strain 1 significantly topped the others (12.33 seeds). An insignificant difference was observed between strain 2 and 3 (11.00 and 10.89 seeds, respectively). Haddarah et al. (2013) reported $7.4 \pm 1.78$ - $14.10 \pm 2.08$ seeds/ pod.

\subsubsection{Average weight of seeds/pod (g)}

Significant differences were observed (Table 8) in 2016 season between the three carob strains, strain 1 surpassed $(2.97 \mathrm{~g})$ followed by strain $3(2.59 \mathrm{~g})$ then strain 2 (1.82 g). In 2017 season, the highest value was scored by strain 3 $(2.25 \mathrm{~g})$ with insignificant difference with strain 1 (2.19 g). Lastly, came strain 2 (1.88 g) with significant differences with the others. Similarly, Haddarah et al. (2013) noted that average weight of seeds/pod ranged $1.36 \pm 0.30-3.10 \pm 0.43 \mathrm{~g}$.

\subsubsection{Average seed/pod percentage}

In both seasons, strain 1 significantly gave the highest value (16.46\% in 2016 and $14.29 \%$ in 2017). In 2016 season, strain 3 recorded the second position then strain 2 with significant difference (12.21 and $9.16 \%$, respectively). In 2017 season, strain 2 and 3 significantly switched their positions (12.88 and 12.08, respectively) as shown in Table (8). The above results recommend that strain 1 may be useful in many industrial products depending on its high seed content. Batlle and Tous (1997) recorded that seeds percentage is about $10 \%$ of the pod also, Haddarah et al. (2013) obtained similar results.

\subsubsection{Pulp chemical contents 3.4.9.1. Total sugars percentage}

In both seasons of the study significant differences were clear between the three strains as shown in Table (9). Strain 1 recorded the highest value $(31.67 \%)$ of total sugars content followed by strain 2 then strain 3 in 2016 ( 25.37 and $23.28 \%$, respectively), but in 2017 season, strain 1 topped $(31.93 \%)$ and strain 2 and 3 switched their positions (20.93 and 22.98\%, respectively). In this study the three Egyptian strains showed lower sugar content which means they can be incorporated into diabetic-friendly foods. The above results are in line with El Kahkahi et al. (2015) who evaluated seven Moroccan carob populations and found that total sugars content ranged $32.41-52.52 \%$.

\subsubsection{Total phenols percentage}

In the $1^{\text {st }}$ season, (Table 9) strain 1 significantly topped the others $(0.327 \%)$. An insignificant difference was observed between strain 2 and 3 (0.281 and $0.245 \%$, respectively). In the $2^{\text {nd }}$ season, strain 1 topped the others $(0.359 \%)$ with insignificant difference with strain $2(0.337 \%)$. Also, insignificant difference was shown between strain 2 and $3(0.319 \%)$. Naghmouchi et al. (2012) obtained total phenols content ranged $0.9-2.3 \mathrm{~g} / \mathrm{Kg}$ in Tunisian carob natural populations.

\subsubsection{Tannins percentage}

In both seasons of the study, as presented in Table (9), strain 1 and 2 didn't differ significantly ( 0.050 and $0.047 \%$ in 2016 as well as 0.052 and $0.055 \%$ in 2017 , respectively), then came strain 3 with significant differences (0.039\% in 2016 and $0.043 \%$ in 2017). The above results showed low tannins content this may be due to the extraction and analytical methodologies, the genotype of the plant, the geographical origin and the climate conditions as reported by Batlle and Tous (1997) who studied extensively the chemical composition of carob for different countries of the Mediterranean area. Tannins contribute to the bitter taste and astringency of the fruit and may interfere with the digestive process by reacting with certain proteins or by inactivating digestive proteolytic enzymes but they have antioxidant properties.

\subsubsection{Total flavonoids content $(\mathrm{mg} / 100 \mathrm{~g})$}

The only clear significant difference (Table 9) was between strain 3 and 2 in the $1^{\text {st }}$ season, strain 3 came first followed by strain 1 then strain 2 (0.077, 0.050 and $0.012 \mathrm{mg} / 100 \mathrm{~g}$, respectively). The only significant difference was between strain 1 and 2 in the $2^{\text {nd }}$ season, strain 1 surpassed the others then came strain 3 and finally strain 2 (0.040, 0.024 and 0.010 
Table (7): Average seed length, width, shape index, weight and thickness of the studied carob strains during 2016 and 2017 seasons.

\begin{tabular}{|c|c|c|c|c|c|c|c|c|c|c|}
\hline \multirow{2}{*}{$\begin{array}{c}\text { Strain } \\
\text { No. }\end{array}$} & \multicolumn{2}{|c|}{$\begin{array}{l}\text { Average seed } \\
\text { length }(\mathrm{cm})\end{array}$} & \multicolumn{2}{|c|}{$\begin{array}{c}\text { Average seed width } \\
(\mathrm{cm})\end{array}$} & \multicolumn{2}{|c|}{$\begin{array}{l}\text { Average seed } \\
\text { shape index }\end{array}$} & \multicolumn{2}{|c|}{$\begin{array}{l}\text { Average seed } \\
\text { weight }(g)\end{array}$} & \multicolumn{2}{|c|}{$\begin{array}{l}\text { Average seed } \\
\text { thickness }(\mathrm{cm})\end{array}$} \\
\hline & 2016 & 2017 & 2016 & 2017 & 2016 & 2017 & 2016 & 2017 & 2016 & 2017 \\
\hline Strain 1 & $0.95 \mathrm{~b}$ & $0.88 \mathrm{~b}$ & $0.70 \mathrm{a}$ & $0.63 \mathrm{~b}$ & $1.36 \mathrm{~b}$ & $1.40 \mathrm{a}$ & $0.20 \mathrm{a}$ & $0.18 \mathrm{~b}$ & $0.36 \mathrm{~b}$ & $0.37 \mathrm{~b}$ \\
\hline Strain 2 & $1.04 \mathrm{a}$ & $0.89 \mathrm{~b}$ & $0.75 \mathrm{a}$ & $0.66 \mathrm{ab}$ & $1.39 \mathrm{a}$ & $1.35 \mathrm{~b}$ & $0.20 \mathrm{a}$ & $0.17 \mathrm{~b}$ & $0.38 \mathrm{ab}$ & $0.40 \mathrm{a}$ \\
\hline Strain 3 & $1.03 \mathrm{a}$ & $0.98 \mathrm{a}$ & $0.75 \mathrm{a}$ & $0.72 \mathrm{a}$ & $1.37 \mathrm{~b}$ & $1.36 \mathrm{~b}$ & $0.17 \mathrm{~b}$ & $0.21 \mathrm{a}$ & $0.40 \mathrm{a}$ & $0.39 \mathrm{a}$ \\
\hline
\end{tabular}

Means designated with the same letter within column in each season is not significantly differ at 0.05 level of probability.

Table (8): Average No. of seeds/pod, average weight of seeds/pod and average seed/pod percentage of the studied carob strains during 2016 and 2017 seasons.

\begin{tabular}{|c|c|c|c|c|c|c|}
\hline \multirow{2}{*}{ Strain No. } & \multicolumn{2}{|c|}{ Average No. of seeds/pod } & \multicolumn{2}{c|}{ Average weight of seeds/pod (g) } & \multicolumn{2}{c|}{ Average seed/pod \% } \\
\cline { 2 - 7 } & $\mathbf{2 0 1 6}$ & $\mathbf{2 0 1 7}$ & $\mathbf{2 0 1 6}$ & $\mathbf{2 0 1 7}$ & $\mathbf{2 0 1 6}$ & $\mathbf{2 0 1 7}$ \\
\hline Strain 1 & $14.67 \mathrm{a}$ & $12.33 \mathrm{a}$ & $2.97 \mathrm{a}$ & $2.19 \mathrm{a}$ & $16.46 \mathrm{a}$ & $14.29 \mathrm{a}$ \\
\hline Strain 2 & $10.00 \mathrm{~b}$ & $11.00 \mathrm{~b}$ & $1.82 \mathrm{c}$ & $1.88 \mathrm{~b}$ & $9.16 \mathrm{c}$ & $12.88 \mathrm{~b}$ \\
\hline Strain 3 & $14.89 \mathrm{a}$ & $10.89 \mathrm{~b}$ & $2.59 \mathrm{~b}$ & $2.25 \mathrm{a}$ & $12.21 \mathrm{~b}$ & $12.08 \mathrm{c}$ \\
\hline
\end{tabular}

Means designated with the same letter within column in each season is not significantly differ at 0.05 level of probability.

Table (9): Percentage of total sugars, total phenols, tannins and total flavonoid content $(\mathrm{mg} / 100 \mathrm{~g})$ in the seedless pods of the studied carob strains during 2016 and 2017 seasons.

\begin{tabular}{|c|c|c|c|c|c|c|c|c|}
\hline \multirow{2}{*}{ Strain No. } & \multicolumn{3}{|c|}{ Total sugars (\%) } & \multicolumn{2}{c|}{ Total phenols (\%) } & \multicolumn{2}{c|}{ Tannins (\%) } & \multicolumn{2}{c|}{$\begin{array}{c}\text { Total Flavonoids } \\
(\mathbf{m g} / \mathbf{1 0 0} \text { g) }\end{array}$} \\
\cline { 2 - 9 } & $\mathbf{2 0 1 6}$ & $\mathbf{2 0 1 7}$ & $\mathbf{2 0 1 6}$ & $\mathbf{2 0 1 7}$ & $\mathbf{2 0 1 6}$ & $\mathbf{2 0 1 7}$ & $\mathbf{2 0 1 6}$ & $\mathbf{2 0 1 7}$ \\
\hline Strain 1 & $31.67 \mathrm{a}$ & $31.93 \mathrm{a}$ & $0.327 \mathrm{a}$ & $0.359 \mathrm{a}$ & $0.050 \mathrm{a}$ & $0.052 \mathrm{a}$ & $0.050 \mathrm{ab}$ & $0.040 \mathrm{a}$ \\
\hline Strain 2 & $25.37 \mathrm{~b}$ & $20.93 \mathrm{c}$ & $0.281 \mathrm{~b}$ & $0.337 \mathrm{ab}$ & $0.047 \mathrm{a}$ & $0.055 \mathrm{a}$ & $0.012 \mathrm{~b}$ & $0.010 \mathrm{~b}$ \\
\hline Strain 3 & $23.28 \mathrm{c}$ & $22.98 \mathrm{~b}$ & $0.245 \mathrm{~b}$ & $0.319 \mathrm{~b}$ & $0.039 \mathrm{~b}$ & $0.043 \mathrm{~b}$ & $0.077 \mathrm{a}$ & $0.024 \mathrm{ab}$ \\
\hline
\end{tabular}

Means designated with the same letter within column in each season is not significantly differ at 0.05 level of probability.

mg/100 g, respectively). El Kahkahi et al. (2015) reported higher total flavonoids content this difference could be attributed due to the extraction and analytical methodologies, the genotype of the plant, the geographical origin and the climate conditions (Batlle and Tous, 1997).

\subsubsection{Total protein content $(\mathrm{g} / \mathbf{1 0 0} \mathrm{g})$}

As shown in Table (10), in 2016 season, strain 1 recorded the highest value (12.76 $\mathrm{g} / 100 \mathrm{~g})$ next came strain $2(12.54 \mathrm{~g} / 100 \mathrm{~g})$ then strain $3(11.65 \mathrm{~g} / 100 \mathrm{~g})$ with insignificant differences between strain 1 and 2 as well as strain 2 and 3. In 2017 season, clear significant differences were noted between the three strains, first came strain $2(15.34 \mathrm{~g} / 100 \mathrm{~g})$ while, strain 3 recorded the second position (12.80 $\mathrm{g} / 100 \mathrm{~g})$ then strain $1(12.02 \mathrm{~g} / 100 \mathrm{~g})$. Battle and Tous (1997) noted that carob pods contain 1-7.6 $\mathrm{g} / 100 \mathrm{~g}$ protein. El Batal et al. (2016) reported lower values of protein $\left(3.05-4.5\right.$ g.100 g $\left.\mathrm{g}^{-1}\right)$, this protein content was slightly lower than the minimum level $\left(5 \mathrm{~g} .100 \mathrm{~g}^{-1}\right)$ required for any food to be labelled as a source of protein, as set by the labelling regulations. The three Egyptian strains under study scored 11.65-15.34 g/100 g which means their pulp is a rich source of protein since they recorded more than twice to triple of the minimum level of the labelling regulations.

\subsubsection{Fiber percentage}

The three strains in 2016 season didn't differ significantly (Table, 10) but in 2017 season, the highest value $(2.03 \%)$ was significantly scored 
Table (10): Total protein content $(\mathrm{g} / \mathbf{1 0 0 g})$, fiber percentage and vitamin $C$ content $(\mathrm{mg} / 100 \mathrm{~g})$ in the seedless pods of the studied carob strains during 2016 and 2017 seasons.

\begin{tabular}{|c|c|c|c|c|c|c|}
\hline \multirow{2}{*}{ Strain No. } & \multicolumn{2}{|c|}{ Total protein $\mathbf{( g / 1 0 0 ~ g ) ~}$} & \multicolumn{2}{|c|}{ Fiber (\%) } & \multicolumn{2}{c|}{ Vitamin C (mg/100g) } \\
\cline { 2 - 7 } & $\mathbf{2 0 1 6}$ & $\mathbf{2 0 1 7}$ & $\mathbf{2 0 1 6}$ & $\mathbf{2 0 1 7}$ & $\mathbf{2 0 1 6}$ & $\mathbf{2 0 1 7}$ \\
\hline Strain 1 & $12.76 \mathrm{a}$ & $12.02 \mathrm{c}$ & $1.79 \mathrm{a}$ & $2.03 \mathrm{a}$ & $19.86 \mathrm{c}$ & $25.06 \mathrm{~b}$ \\
\hline Strain 2 & $12.54 \mathrm{ab}$ & $15.34 \mathrm{a}$ & $1.79 \mathrm{a}$ & $1.25 \mathrm{~b}$ & $26.06 \mathrm{~b}$ & $25.34 \mathrm{~b}$ \\
\hline Strain 3 & $11.65 \mathrm{~b}$ & $12.80 \mathrm{~b}$ & $1.40 \mathrm{a}$ & $0.94 \mathrm{~b}$ & $27.29 \mathrm{a}$ & $28.39 \mathrm{a}$ \\
\hline
\end{tabular}

Means designated with the same letter within column in each season is not significantly differ at 0.05 level of probability.

by strain 1 while, insignificant difference was found between strain 2 and 3 (1.25 and $0.94 \%$, respectively). The three carob strains under study showed lower fiber content than that was reported by Haddarah et al. (2013) this may be due to the extraction and analytical methodologies, the genotype of the plant, the geographical origin and the climate conditions as reported by Batlle and Tous (1997).

\subsubsection{Vitamin C content (mg/100g)}

In both seasons of the study strain 3, 2 and 1 showed a descending order as shown in Table (10), 27.29, 26.06 and $19.86 \mathrm{mg} / 100 \mathrm{~g}$, respectively with significant differences in 2016 season as well as 28.39, 25.34 and 25.06 $\mathrm{mg} / 100 \mathrm{~g}$, respectively with insignificant difference between strain 1 and 2 only in 2017 season. Gubbuk et al. (2010) found that vitamin $\mathrm{C}$ content of three Turkish genotypes ranged $8.07-10.41 \mathrm{mg} / 100 \mathrm{~g}$ while, in this study ranged $19.86-28.39 \mathrm{mg} / 100 \mathrm{~g}$ this higher content has a nutritional benefit as it's been proved that shortage of vitamin $\mathrm{C}$ causes scurvy disease.

\subsubsection{Molecular analysis based on ISSR-PCR}

3.4.10.1. ISSR fingerprinting of the three female carob strains

The ISSR analysis was performed on the three DNA samples representing the three carob strains using four ISSR primers. Table (11) and Fig. (6) illustrate the ISSR profile of the three carob strains. A total of 43 amplicons, amplified fragments, ranged from $200 \mathrm{bp}$ to $1264 \mathrm{bp}$, were obtained by the tested primers with an average of 10.75 amplicons/primer. ISSR primers HB12 and HB14 exhibited the highest number of fragments (15 and 11 amplicons, respectively), followed by primers HB9 and HB8 (9 and 8 amplicons, respectively) as shown in Table (11).

The total number of polymorphic bands was 23 with an average of 5.75 polymorphic amplicons/primer. This represents a level of polymorphism about of $53.48 \%$ (Table, 11). The number of polymorphic bands varied among the different primers. Primers HB-14 generated 9 polymorphic bands with $81.81 \%$ polymorphism while, primer HB-8 showed lowest level of polymorphism $37.5 \%$ (Table, 11).

\subsubsection{Carob strains-ISSR specific markers}

Twenty one out of the 43 ISSR-bands (about $48.8 \%$ ) were found to be useful as strain-unique markers (Table 12), which could be distinguished as 8 unique bands for strains 1,7 unique bands for strain 2 and 6 unique bands for strains 3 . The number of ISSR-PCR fragments generated by using the four primers, and could be used as strain-specific markers were arranged descending as, primer HB14 (eight markers), Primers HB12 (six markers), primer HB9 (four markers) and HB8 (three markers).

Thus, the carob strain could be identified by strain-specific ISSR markers as follow (Table, 12); Strain 1 is characterized by eight markers (948 bp, 446 bp, 366 bp, 281 bp and 260 bp) as a positive markers and (1264 bp, $572 \mathrm{bp}$ and 326 bp) as negative markers, Strain 2 is recognized by three negative markers (700 bp, $525 \mathrm{bp}$ and $310 \mathrm{bp}$ ) and four as a positive markers (375 bp, $622 \mathrm{bp}, 1137 \mathrm{bp}$ and $1031 \mathrm{bp})$. Strain 3 is characterized by three as negative markers ( 873 bp, $494 \mathrm{bp}$ and $451 \mathrm{bp}$ ) and three as positive markers (1219 bp, 1025 bp and 423 bp).

\subsubsection{Genetic similarity and cluster analysis based on ISSR markers}

The ISSR data were used to estimate the genetic similarity among the three carob strains by using UPGMA computer analysis (Table 13). The highest similarity index $(0.77)$ was recorded between strain 1 and strain 2 and also between strain 2 and strain 3, while strain 3 is genetically far from strain 1.

A dendrogram for the genetic relationship among the three carob strains was carried out as in Fig. (7) which separated the three carob strains into two major groups. The first group included strain 1 and strain 2, while the second group included strain 3 alone. 
Table (11): Statistics of the ISSR amplicons for the three female carob strains based on the four ISSR primers.

\begin{tabular}{|c|c|c|c|c|c|c|}
\hline \multirow[b]{2}{*}{$\begin{array}{l}\text { ISSR } \\
\text { primers } \\
\text { code }\end{array}$} & \multicolumn{6}{|c|}{ Amplified fragments } \\
\hline & 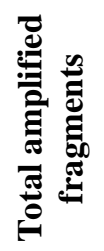 & 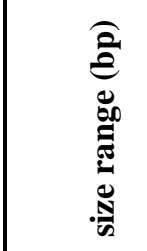 & 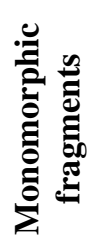 & 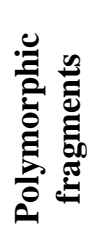 & 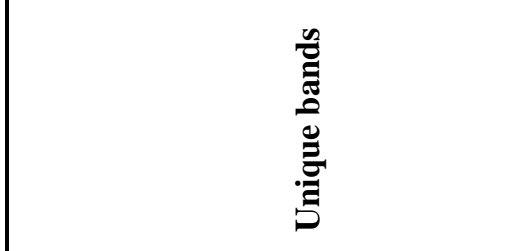 & 总 \\
\hline HB-8 & 8 & $375-1264$ & 5 & 3 & $\begin{array}{l}\text { C1(-) } 1264 \text { bp } \\
\text { C3 ((-) } 494 \text { bp (+) } 423 \text { bp) }\end{array}$ & 37.5 \\
\hline HB-9 & 9 & 260-1219 & 4 & 5 & 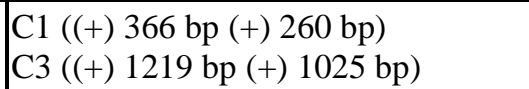 & 55.55 \\
\hline HB-12 & 15 & 200-1119 & 9 & 6 & $\begin{array}{l}\text { C1((-) } 572 \mathrm{bp},(+) 446 \mathrm{bp}(-) 326 \mathrm{bp}) \\
\text { C2 ((+) } 1031 \mathrm{bp}(-) 700 \mathrm{bp} \\
\text { C3 ((-) } 873 \mathrm{bp})\end{array}$ & 40.00 \\
\hline HB-14 & 11 & $281-1137$ & 2 & 9 & & 81.81 \\
\hline Total & 43 & - & 20 & 23 & & $53.48 \%$ \\
\hline Average & 10.75 & - & 5 & 5.75 & & $53.48 \%$ \\
\hline
\end{tabular}

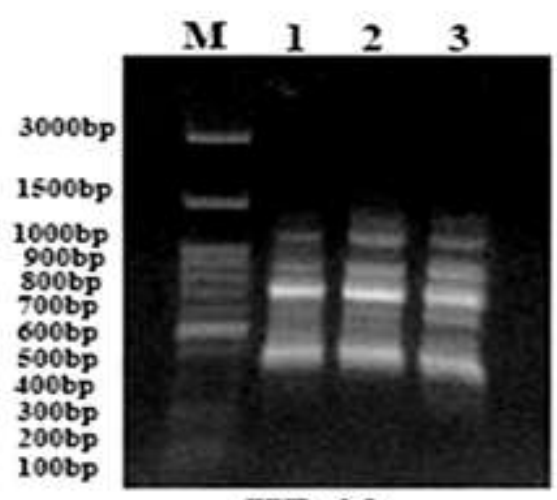

HB-08

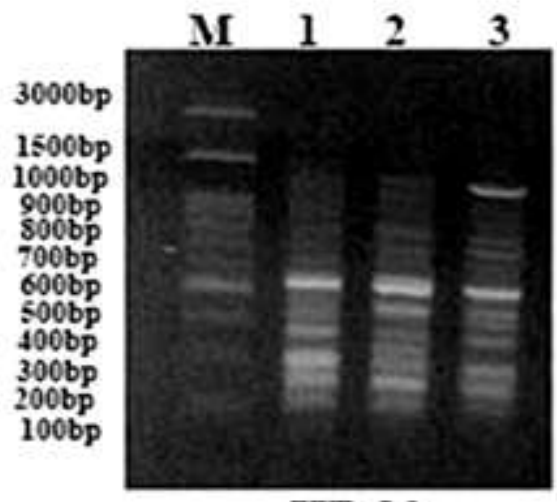

HB-12

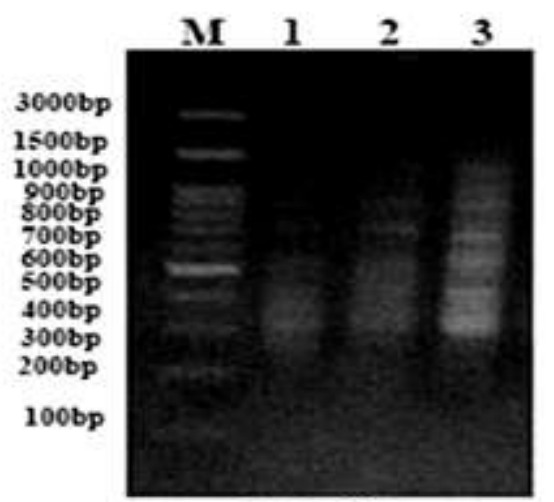

HB-09

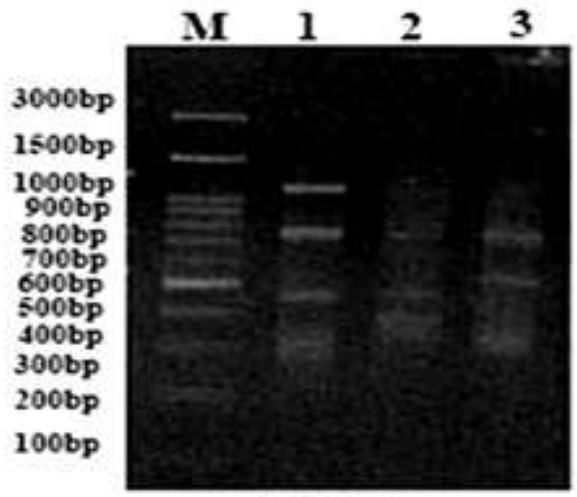

HB-14

Fig. (6): ISSR amplified fragments of the three female carob strains using four primers, $M=100 \mathrm{pb}$ DNA ladder $\left(\right.$ Stratagene $\left.{ }^{\circledR}\right)$, lane1 $=$ Strain 1, lane2= Strain 2 and lane 3= Strain 3. 


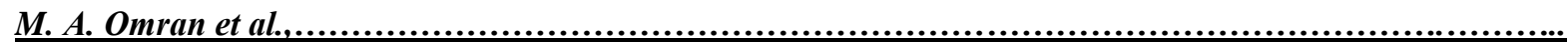

Table (12): Strain-specific ISSR markers for the three female carob strains resulted from the four ISSR primers.

\begin{tabular}{|c|c|c|c|c|}
\hline Primer & Strain 1 & Strain 2 & Strain 3 & Total \\
\hline HB-8 & (-) 1264 bp & -- & $\begin{array}{l}\text { (-) } 494 \mathrm{bp} \\
(+) 423 \mathrm{bp}\end{array}$ & 3 \\
\hline HB-9 & $\begin{array}{l}\text { (+) } 366 \mathrm{bp} \\
\text { (+) } 260 \mathrm{bp} \\
\end{array}$ & -- & $\begin{array}{l}\text { (+) } 1219 \mathrm{bp} \\
(+) 1025 \mathrm{bp}\end{array}$ & 4 \\
\hline HB-12 & $\begin{array}{l}\text { (-) } 572 \mathrm{bp} \\
\text { (+) } 446 \mathrm{bp} \\
\text { (-) } 326 \mathrm{bp}\end{array}$ & $\begin{array}{l}(+) 1031 b p \\
(-) 700 \mathrm{bp}\end{array}$ & (-) $873 \mathrm{bp}$ & 6 \\
\hline НB-14 & $\begin{array}{l}\text { (+) } 948 \mathrm{bp} \\
\text { (+) } 281 \mathrm{bp}\end{array}$ & $\begin{array}{c}\text { (+) } 1137 \mathrm{bp} \\
(+) 622 \mathrm{bp} \\
(-) 525 \mathrm{bp} \\
(+) 375 \mathrm{bp} \\
(-) 310 \mathrm{bp}\end{array}$ & (-) $451 \mathrm{bp}$ & 8 \\
\hline Total & 8 & 7 & 6 & 21 \\
\hline
\end{tabular}

Table (13): Similarity Matrix between the three female carob strains based on ISSR analysis.

\begin{tabular}{|c|c|c|c|}
\hline Lane & Strain 1 & Strain 2 & Strain 3 \\
\hline Strain 1 & 1 & & \\
\hline Strain 2 & 0.77 & 1 & \\
\hline Strain 3 & 0.76 & 0.77 & 1 \\
\hline
\end{tabular}
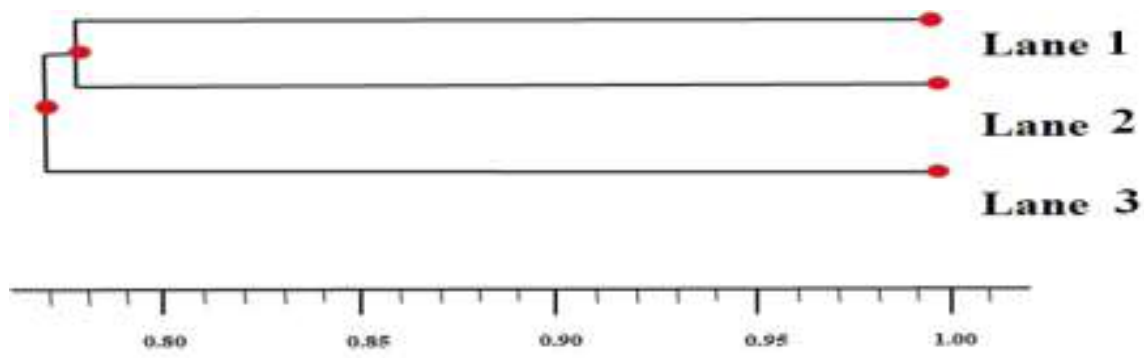

Fig. (7): Dendrogram for the three female carob strains accessions (collected from Giza Governorate) constructed from the ISSR generated data using UPGMA method and similarity matrices computed according to Dice's similarity coefficient.

It can be concluded from ISSR analysis of the three carob strains that there was a genetic differentiation among them. The dendrogram constructed from ISSR generated data using UPGMA based analysis confirmed the degree of diversity between the three carob strains.

The classification showed relatedness with their correlation between morphological and molecular analysis which separated the three carob strains into two major groups. The first group included strain 1 and strain 2 while, the second group included strain 3 alone which explains the closely morphological and physiological characteristics between strain 1 and 2 , while the second group included strain 3 which was special concerning pod length, width and weight, pulp weight and vitamin C content.

\section{Conclusion}

Focusing on seed content and pod production, the three female de Egyptian carob strains of this study showed higher protein and vitamin $\mathrm{C}$ content while they recorded lower fiber, tannins, total flavonoids and sugar contents compared with the previously mentioned studies. In both seasons, strain 1 was elegant regarding average No. of seeds/pod, average weight of seeds/pod, percentage of seed/pod, total sugars, total phenols and fiber percentages while, strain 2 had 
greater protein content Nevertheless, strain 3 was special concerning yield, pod length, pod width, pod weight, pulp weight and vitamin $\mathrm{C}$ content. Strain 1 is suitable for many industrial demands which are interested in carob bean gum (CBG), seeds powder and carob germ flour. Strain 3 is the best for industries which uses the seedless pods for the production of carob flour, bread, powder, jam, juice and molasses. The use of ISSR markers confirmed the importance of genetic studies to explain the correlation between morphological, physiological and genetic characteristics.

\section{REFERENCES}

Adawy S. S., Hussein E. A., Saker M. M. and El-Itriby H. A. (2004). Intra and Inter varietal variation of Upper Egypt date palm cultivars (Phoenix dactylifera L.): 1. as revealed by RAPD and ISSR markers. Proceed Int'l. Conf. Genet. Eng. \& Appl., Sharm El-Sheikh, South Sinai, Egypt (April, 8-11, 2004) pp: 165179.

AOAC (1970). Official Method of Analysis of the Association of Official Analytical Chemists, Washington D. C., USA.11 ed. pp. 240.

AOAC (1990). Official methods of analysis of the Association of Official Analytical Chemists. Washington, D. C., USA. $15^{\text {th }}$ ed. pp. 1058-1059.

AOAC (2005). Official Method of Analysis of the Association of Official Analytical Chemists, Gaithersburg, Maryland, USA. $18^{\text {th }}$ ed.

Awad N. A. (2014). Relationships among phenotypic, chemical and genetic characteristics of some selected and evaluated carob strains (Ceratonia siliqua L.). Int'l. J. Plant \& Soil Sci. 3 (11): 1415-1427.

Batlle I. and Tous J. (1997). Carob tree. Ceratonia siliqua L. Promoting the conservation and use of underutilized and neglected crops. 17, Institute of Plant Genetics and Crop Plant Research, Gatersleben/International Plant Genetic Resources Institute, Rome, Italy. pp 92.

Biner B., Gubbuk H., Karham M., Aksu M. and Pekmeczi M. (2007). Sugar profiles of the pods of cultivated and wild types of carob bean (Ceratonia siliqua L.) in Turkey. Food Chem. 100 (4): 14531455.
Bulca S. (2016). Some properties of carob pod and its use in different areas including food technology. Scientific Bulletin, Series F. Biotechnologies, Vol. XX: 142-147.

http://biotechnologyjournal.usamv.ro/in dex.php/scientific-papers/current/8administrative/272-scientific-bulletinseries-f-biotechnologies-vol-xx-2016.

Dellaporta S. L., Wood J. and Hicks J. B. (1983). A plant DNA mini preparation. Version III. Plant Mol. Biol., Rep., 1: 19-21.

Djeridane A., Yousfi M., Nadjemi B., Boutassouna D., Stocker P. and Vidal N. (2006). Antioxidant activity of some Algerian Medicinal plants extracts containing phenolic compounds. Food Chem. 97 (4): 654-660.

El Batal H., Hasib A., Dehbi F., Zaki N., Ouatmane A. and Boulli A. (2016). Assessment of nutritional composition of Carob pulp (Ceratonia Siliqua L.) collected from various locations in Morocco. J. Mater. Environ. Sci. 7 (9): 3278-3285.

El Kahkahi R., Zouhair R., Diouri M., Ait Chitt M. and Errakhi R. (2015). Morphological and biochemical characterization of Morocco carob tree (Ceratonia siliqua L.). Int'l. J. Biol. Med. Res. 6 (2):4946-4952.

Fillet P. and Roulland I. M. (1998). Caroubin: A gluten-like protein isolate from carob bean germ. Cereal Chem., 75:488 - 492.

Fletcher R. (1997). XIII. Carob agroforestry in Portugal and Spain, The Australian New Crops Newsletter. Available in: http//www.newcrops.uq.edu.au/ public1.htm.

Food and Agriculture Organization of the United Nations (FAO). (2001). Non-wood Forest Products in the Near East: A Regional and National Overview. FAO Corporate Document Repository, 3.Country reports, 3.8, Lebanon. Retrieved on 12-18-2006 from http://www.fao.org/docrep/003/Y1797E/ y1797e13.htm

Food and Agriculture Organization of the United Nations (FAO). (2016). http://www.fao.org/faostat/en/\#search/C $\underline{\text { arobs }}$

Gubbuk H., Kafkas E., Guven D. and Gunes E. (2010). Physical and phytochemical 
profile of wild and domesticated carob (Ceratonia siliqua L.) genotypes. Spanish J. Agric. Res., 8 (4): 1129-1136. Haddarah A., Ismail A., Bassal A., Hamieh T., Ioannou I. and Ghoul M. (2013). Morphological and chemical variability of Lebanese carob varieties. Eur. Sci. J. 9 (18): 353-369.

Hussein E. A., Mohamed A. A., Attia S. and Adawy S. S. (2006). Molecular characterization and genetic relationships among cotton genotypes 1RAPD, ISSR and SSR analysis. Arab J. Biotech., 9: 313-328.

Iipumbu L. (2008). Compositional analysis of locally cultivated carob (Ceratonia siliqua L.) cultivars and development of nutritional food products for a range of market sectors. M.Sc. Thesis, Department of Food Science, Faculty of AgriSciences, Stellenbosch University. Western Cape Winelands. South Africa. $117 \mathrm{pp}$.

Karababaa E. and Coskunerb Y. (2013). Physical properties of carob bean (Ceratonia siliqua $\mathrm{L}$.): An industrial gum yielding crop. Ind. Crops Prod., 42: 440- 446.

Kawamura S. (1967). Quantitative paper chromatography of sugars of the cotyledon, hull and hypocotyl of soybeans of selected varieties. Tech. Bull. Fac. Agric. Kagawa Univ., 18 (2): 117-131.

Konaté I., Filali-Maltouf A. and Berraho E. (2007). Diversity analysis of Moroccan carob (Ceratonia siliqua L.) accessions using phenotypic traits and RAPD markers, Acta Bot. Malacitana, 32: 7990

Makris D. P. and Kefalas P. (2004). Carob pods (Ceratonia siliqua L.) as a source of polyphenolic antioxidants. Food Technol. Biotech. 42(2): 105-8.

Maza M. P., Zamora R., Alaiz M., Hidalgo F. J., Millan I. and Vioque I. (1989). Carob bean germ seed (Ceratonia Siliqua L.) study on the oil and proteins, J. Sci. Food \& Agric., 46: 495 - 502.

Miller G. L. (1959). Use of dinitrosalicylic acid reagent for determination of reducing sugars. Anal. Chem., 31 (3): 426-428.

Ministry of Agriculture and Land Reclamation (2016). Bull. Agric. Stat., part 2. pp.347.

Naghmouchi S., Khouja M. L., Khaldi A., Rejeb M. N., Zgoulli S., Thonart P. and Boussaid M. (2012). Biochemical Diversity of Wild Carob Tree Populations and Its Economic Value. https://www.intechopen.com/books/topi cs-in-conservation-biology/tunisianceratonia-siliqua-carob-naturalpopulations-biochemical-compositiondiversity-of-pulp-and-k

Nasar-Abbas S. M., e-Huma Z., Vu T., Khan M. K., Esbenshade $\mathrm{H}$. and Jayasena V. (2016). Carob Kibble: A bioactive-rich food ingredient. Compr. Rev. Food Sci. \& Food Saf., 15: 63-72.

Plummer D. T. (1971). An introduction to practical biochemistry. McGraw-Hill Book Co. (UK), Ltd., Maidenhead, Berkshire, UK., 369 pp.

Snedecor G. W. and Cochran W.G. (1980). Statistical methods. Six ${ }^{\text {th }}$ ed. Iowa State Univ. press, Ames, Iowa, U.S.A., p. 507.

Swain T. and Hillis W. E. (1959). The phenolic constituents of Prunus domestica. 1. The quantitative analysis of phenolic constituents. J. Sci. Food Agric., 10 (1): 63-68.

Tous J., Romero A., Hermoso J. F., Ninot A., Plana J. and Batlle I. (2009). Agronomic and Commercial Performance of Four Spanish Carob Cultivars. Hort. Technol., 19 (2): 465-470.

Waller A. and Duncan D. B. (1969). Multiple range and multiple test. Biometrics, 11:1-24.

Youssef M. K. E., El-Manfaloty M. M. and Ali H. M. (2013). Assessment of proximate chemical composition, nutritional status, fatty acid composition and phenolic compounds of carob (Ceratonia siliqua L.). Food \& Public Health, 3(6): 304308.

Zietkiewicz E., Rafalski A. and Labuda D. (1994). Genome fingerprinting by simple sequence repeats (ISSR)anchored polymerase chain reaction amplification. Genomics, 20: 176-183. 
الصفات المورفولوجية والفسيولوجية والكميائية الحيوية الجينيية لثلاثة سلالات من أثجار الخروب المؤنثة المصرية ماهر أحمد عمران ـ عبد ذى الجلال زكريا حسن - هالة نجيب محمد

قسم الزيتون و فاكهة المناطق شبة الجافه ـ معهد بحوث البساتين ـ مركز البحوث الزر اعية ـ الجيزة- مصر

\section{ملخص}

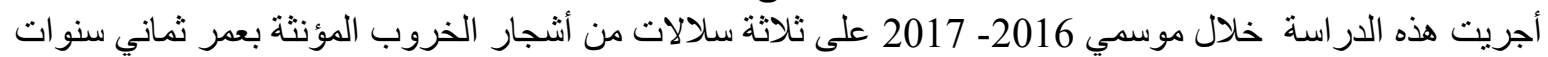

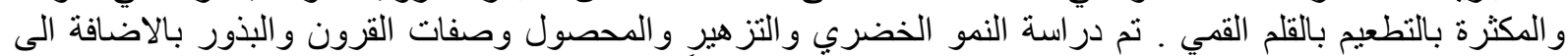

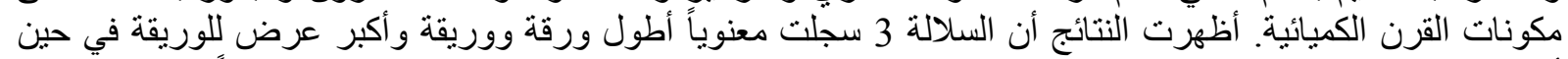

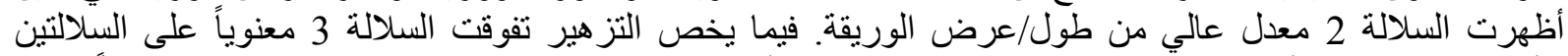

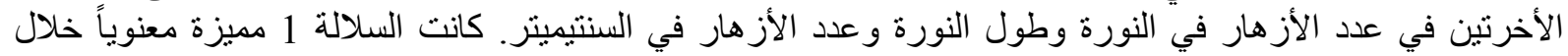

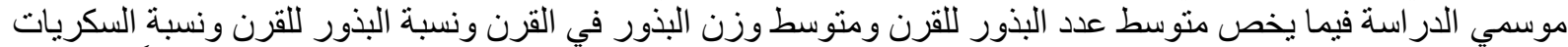

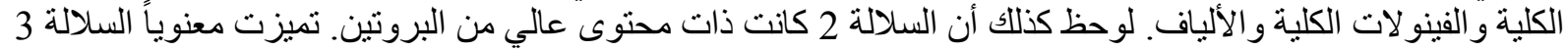

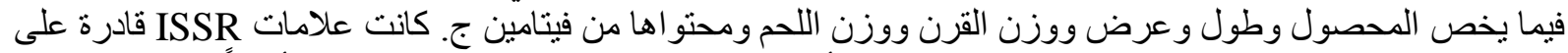

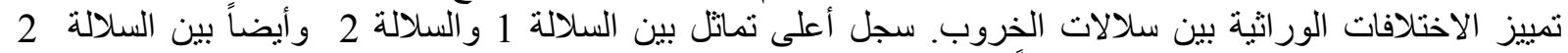
و السلالة 3 بينما كانت السلالة 3 بعيدة جينياً عن السلالة البرول 1.

المجلة العلمية لكلية الزراعة - جامعة القاهرة ـ المجلد (69) العدد الرابع (أكتوبر 2018):401-387. 